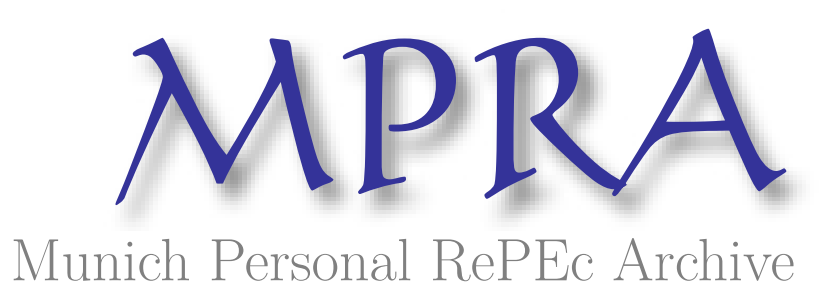

\title{
Does Foreign Aid Promote Democracy?
}

Knack, Stephen

World Bank

1 July 2003

Online at https://mpra.ub.uni-muenchen.de/24855/

MPRA Paper No. 24855, posted 10 Sep 2010 16:01 UTC 


\title{
Does Foreign Aid Promote Democracy?
}

July 2003

\author{
Stephen Knack*
}

*Senior Research Economist, The World Bank, 1818 H Street NW, Washington DC 20433. Email: sknack@worldbank.org. Phone: 202-458-9712. Fax: 202-522-1155. Gary Anderson and Muhammed Hameed provided valuable research assistance. The editors and several anonymous referees provided helpful comments. The conclusions of this paper are not intended to represent the views of the World Bank, its Executive Directors, or the countries they represent. 


\begin{abstract}
Aid potentially can contribute to democratization in several ways: (1) through technical assistance focusing on electoral processes, the strengthening of legislatures and judiciaries as checks on executive power, and the promotion of civil society organizations, including a free press; (2) through conditionality; and (3) by improving education and increasing per capita incomes, which research shows are conducive to democratization. This study provides a multivariate analysis of the impact of aid on democratization in a large sample of recipient nations over the 1975-2000 period. Using two different democracy indexes and two different measures of aid intensity, no evidence is found that aid promotes democracy. This result is robust to alternative model specifications and estimation techniques, including the use of exogenous instruments for aid. Results are similar if the analysis is confined to the post-Cold War period (1990-2000), despite the reduced dependence of the U.S. and other donors on proWestern authoritarian regimes among aid recipient nations.
\end{abstract}




\section{INTRODUCTION}

Foreign aid potentially can contribute to democratization in several ways: (1) through technical assistance focusing on electoral processes, the strengthening of legislatures and judiciaries as checks on executive power, and the promotion of civil society organizations, including a free press; (2) through conditionality; and (3) by improving education and increasing per capita incomes, which research shows are conducive to democratization. However, several authors have suggested that aid could undermine accountability processes essential for healthy democratic government, or even encourage violent conflict and coup attempts.

This study provides a multivariate analysis of the impact of aid on democratization in a large sample of recipient nations over the 1975-2000 period. Using several alternative democracy indexes and measures of aid intensity, no evidence is found that aid promotes democracy. This evidence does not necessarily imply that no democracy-promoting programs work as intended. But those successful programs appear to be either too few and far between for their effects to be detectable in the aggregated data, or are compensated by other effects of aid that tend to undermine democratic development.

Section 2 briefly describes democracy-building efforts of major bilateral donors, and reviews literature suggesting that aid can have negative effects on democratization and the quality of governance. Section 3 describes the data used in the analysis, which is presented in section 4. Implications of the findings are discussed in the concluding section. 


\section{BACKGROUND}

Many foreign aid donors include the promotion of democratic government as a major goal of their aid programs. The U.S. Agency for International Development (USAID) alone spends more than $\$ 700$ million annually on democracy-related programs, including elections support, the strengthening of parliaments, judiciaries and political parties, and fostering the growth and power of "civil society organizations" such as labor unions and women's and human rights groups (Carothers, 1999). ${ }^{1}$ Although technical assistance specifically targeted at democracy promotion is a small fraction of all aid ${ }^{2}$, the U.S. and other donors often condition grants or loans intended for general budget support on performance in the areas of civil liberties, the conduct of elections, and respect for the rule of law. In 1975, section 116 was added to the Foreign Assistance Act, conditioning U.S. aid on respect for human rights and civil liberties.

Even when awarded for other purposes, aid can promote democracy indirectly by "modernizing" societies. Literacy and increased incomes are key aspects of modernization often believed to increase the demand for democratic government (e.g. Lipset, 1959; Almond and Powell, 1965). Much aid of course is intended to improve economic growth, and many aid programs are targeted at improving literacy and access to education. Empirical studies have linked schooling and per capita income to democratization (Barro, 1997; Burkhart and LewisBeck, 1994; Lipset, 1959).

In addition to USAID, most donor nations and numerous multilateral institutions sponsor democracy programs. Even international financial institutions such as the World Bank that do not explicitly promote democratization commit sizeable resources to "good governance" programs 
intended to strengthen accountability and the rule of law in recipient countries.

If technical assistance and/or conditionality is effective in promoting democratic governance - either directly or through increasing education and income levels - then higher levels of foreign aid receipts should be associated with increases in democracy. In fact, USAID is not hesitant about claiming credit for the spread of democracy, as one of many examples "of what the one half of one percent of the federal budget dedicated to economic and humanitarian assistance has achieved":

There were 58 democratic nations in 1980. By 1995, this number had jumped to 115 nations. USAID provided democracy and governance assistance to 36 of the 57 nations that successfully made the transition to democratic government during this period. ${ }^{3}$

Obviously the fact that many aid recipients have become more democratic does not by itself imply cause and effect. Examples of successful programs in particular countries may convincingly demonstrate that some types of aid can sometimes be beneficial, but tell us nothing about the overall effectiveness of aid in promoting democracy. Furthermore, studies generally find that conditioning aid on reform in recipient nations is largely ineffective (Dollar and Pritchett, 1998; Collier, 1997; Crawford, 1997). ${ }^{4}$

Many scholars and aid practitioners have even argued that foreign aid can undermine democratic government. Friedman (1958) has argued that foreign aid is inimical to civil liberties and democracy. Because most aid goes to governments, it tends "to strengthen the role of the government sector in general economic activity relative to the private sector." Democracy and freedom, Friedman and others have argued, are less likely to emerge and to survive where most 
economic activity is organized by the public sector. Other scholars have argued that aid potentially weakens governmental accountability, by retarding development of a healthy "civil society" underpinning democracy and the rule of law. The evolution of democracy and the rule of law in the West was critically related to monarchs' needs for tax revenues, particularly for fighting wars (Tilly, 1990; North, 1990: 113). Elites who provided monarchs with most of their tax revenues in turn demanded accountability from government. England is the prototypical example, with the Glorious Revolution being the most prominent event in the process of increasing accountability of monarchs to elites, followed eventually by gradual extension of the suffrage. Foreign aid may short-circuit these processes in developing countries, by reducing government's dependence on its citizenry for tax revenues (Moore, 1998; Karl, 1997: 57, 190). With high levels of aid, recipient governments are accountable primarily to foreign donors rather than to taxpayers: "those with the loudest single voice on revenue and expenditure decisions are international lending agencies" (Brautigam, 1992: 11).

High aid levels may also reinforce executive dominance in new democracies, as donors often fund projects outside of the budget, precluding any review by parliament (Brautigam, 2000). The recent report of the congressionally-appointed International Financial Institution Advisory Commission (2000) noted:

The use of IMF resources and conditionality to control the economies of developing nations often undermines the sovereignty and democratic processes of member governments receiving assistance. IMF staff often admit (with pride) that the executive branch of borrowing nations likes to use IMF conditions to exact concessions from their legislatures. While this mechanism may sometimes work to achieve desirable reforms, it often does so by shifting the balance of power within countries in ways that distort the constitutionally established system of checks and 
balances.

Aid may also encourage coup attempts and political instability, by making control of the government and aid receipts a more valuable prize (Grossman, 1992), reducing the prospects for democratic governance. It is widely acknowledged that violent competition for control over large-scale food aid contributed to the breakdown of government in Somalia (e.g. Maren, 1997).

In light of these various arguments, comprehensive analyses are needed to determine whether on balance aid promotes, undermines, or has no impact on democracy. This study examines the issue empirically, using cross-country data for the period 1975-2000. There is a growing cross-country empirical literature on aid's effectiveness in promoting economic development (e.g., Easterly et al., 2003; Burnside and Dollar, 2000; Isham et al., 1997; Boone, 1996). Svensson (1999) finds that the impact of aid on income growth is higher in more democratic nations, as measured by the Freedom House indexes found that economic rates of return on World Bank-financed government projects were higher in countries with higher scores on the Freedom House indicator of civil liberties.

Relatively few cross-country statistical studies of aid effectiveness have addressed political and institutional issues. Knack (2001) finds that higher levels of aid worsen corruption and bureaucratic quality, correcting for the potential endogeneity of aid. Svensson (2000) finds that aid is associated with greater corruption in ethnically heterogeneous countries but not in more homogeneous countries. Using a case study approach, Crawford (1997) analyzes 29 instances of politically-motivated aid sanctions in the 1990-96 period, and finds a very modest record of success. In only 13 cases were sanctions followed by an improvement in the Freedom 
House indexes, and in several of these "successes" Crawford concludes that aid sanctions played little role in the outcome. The present study examines aid's impact on democratic development in a large sample of aid recipients, finding no evidence that aid on balance has promoted or undermined democracy in recipient nations.

Several studies investigate the impact of human rights' protection on aid allocations, primarily U.S. aid (Apodaca, 2001; Blanton, 2000; Meernik et al., 1998; McCormick and Mitchell, 1988; Cingranelli and Pasquarello, 1985). Findings from these studies are very mixed, and they do not attempt to correct for the possibility that causation might be from aid to human rights rather than the reverse. Nevertheless, the existence of these studies suggests that any causal relationship between aid and democratization could go in either direction. Therefore, the empirical work below, which includes aid from all donors, not only the U.S., explicitly corrects for the potential endogeneity of aid to democratization.

\section{DATA AND HYPOTHESES}

Beginning in the early 1970s, Freedom House (various years) has annually provided two sets of ratings for all countries, one on the extent of political freedoms, and the other on civil liberties. These ratings have been used by numerous researchers in economics (e.g. Barro, 1997) and political science (e.g. Burkhart and Lewis-Beck, 1994) as measures of democracy. Countries are rated on a 1-7 scale, with higher values indicating less freedom. In the empirical analysis here, the scales are reversed so that a higher value indicates a country is more democratic.

The Appendix describes the criteria used by Freedom House in making its evaluations. The political freedoms index better approximates standard definitions of democracy than the civil 
liberties index, but the latter better captures many of the civil society dimensions of democracy building that are the focus of many USAID and other donor projects. Civil liberties such as freedom of speech, association and assembly are necessary for elections to be free, fair, and to represent informed citizen preferences, and thus is an integral part of democracy (USAID, 1998). Therefore, a combined index that ranges from 2 to 14 in value will be used in analyses below. ${ }^{5}$ From 1972 until 1989, Raymond Gastil produced all of the Freedom House ratings. Because the judgments and methods of those replacing him may have differed, his departure creates the possibility of a break in the data that invalidates use of the full data series to evaluate changes over time within countries. However, examination of year-to-year correlations in the indexes before, during and after the transition provide no indication of a break in the data. In any event, results reported in the analysis below do not differ when only the post-1989 Freedom House data are used. All results reported using the Freedom House index are also replicated using an alternative democracy index.

The alternative index is based on indicators provided in the Polity IV data set (Marshall and Jaggers, 2002). That data set provides a 10-point scale of democracy based on evaluations of how executives are selected, and of whether or not there are any effective institutional checks on their power. Also included is a 10-point autocracy scale, with higher values representing some combination of less competitive processes for selecting chief executives, and fewer constraints on their authority. Additional detail on these indicators is contained in Marshall and Jaggers (2002).

Following standard practice (e.g. Gleditsch and Ward, 2000), the democracy index used 
in the analysis is constructed by taking the difference in the Polity 98 democracy and autocracy indexes. The resulting index can vary from a high of +10 to a low of -10 .

While the Freedom House democracy indexes attempt to reflect rights afforded a country's population, the Polity index is intended to reflect institutional characteristics of a country's government, particularly how open and competitive are the processes for selecting chief executives. The conceptual links between the Freedom House indexes and donors' democracy-promoting programs are obvious; as noted, donors even use those indexes as indicators of progress. Aid in the form of support for elections and electoral processes could equally affect the Polity index, by enhancing the openness and competitiveness of elections.

The Freedom House and Polity democracy indicators are in close (but not perfect) agreement, not only on levels but also on changes in democracy over the 1975-99 period. For 1975 , the Spearman rank correlation is .73, and for 1996 levels is .89 , for the 96 countries included in the aid-democracy tests reported in section 4 below. Changes over the 1975-99 period are correlated at .76 $(\rho=.0001)$. Figure 1 graphically portrays the correspondence in the 1975-99 changes in the Freedom House and Polity democracy indexes.

Two alternative measures of aid intensity or dependence are used in the analysis: "official development assistance" (ODA) as a percentage of GNP, and as a percentage of government expenditures. Averages over the 1975-99 period were constructed for aid/GNP and aid as a share of government spending. Aid as a share of GNP and aid as a share of government expenditures are correlated at $.86(\rho=.0001) .{ }^{6}$ Annual data on aid are available from the World Bank's World Development Indicators, based on data collected by the OECD's Development Assistance 
Committee, dating from 1975. Aid includes grants, and concessionary loans with a grant element of more than 25 percent. Aid is measured net rather than gross, i.e. current loan repayments are subtracted. Military assistance is excluded.

If aid promotes democracy, then countries with higher aid levels should exhibit improving ratings on the democracy indexes over time, other things equal. ${ }^{7}$ Accordingly, the dependent variable analyzed here is the end of period (2000) minus the initial period (1975) ratings on the democracy indexes. ${ }^{8}$

Control variables include the initial democracy index value, initial (log of) per capita income, growth in per capita income from 1975-99, initial levels of illiteracy, the change in illiteracy from 1975-99, and a set of regional dummy variables. ${ }^{9}$ The initial democracy index captures regression-to-the-mean effects, and controls for the limited opportunity of highlydemocratic countries to increase their ratings (the Freedom House and Polity indexes respectively have upper-bound values of 14 and 10).

Socioeconomic development has long been believed to be conducive to the emergence (e.g. Lipset, 1959; Burkhart and Lewis-Beck, 1994) or survival (Przeworski and Limongi, 1997) of democracy, so changes in democracy may be related to changes in per capita income. Growth of per capita income is measured as the average annual change from 1975-99.

Literacy is an alternative measure of socioeconomic development emphasized by "modernization" theories of democratization. The measure used here is the change in illiteracy from 1975 to 1999, with larger numbers indicating a larger decline (i.e. improvement) over time. $^{10}$ 
Controlling only for changes, and not initial levels, of per capita income and literacy requires the strong assumption that the democracy indexes as of 1975 already reflected any impacts of initial levels. If there are lags in their effects, or lags in perceptions of the experts who provide the democracy ratings, initial levels of income and literacy may also be associated with changes in the democracy indexes. Therefore, levels of income per capita and illiteracy in 1975 are included in the regressions.

There is some evidence that democratization occurs in waves. Regardless of whether or not a nation is "modernizing," its likelihood of democratizing is partly dependent on political changes in its neighbors. The "third wave" of democratization (Huntington, 1991) occurred during the period analyzed here, and involved primarily nations in Sub-Saharan Africa, Latin America and the Caribbean, and in Eastern Europe. Dummy variables for each of these country groups are therefore included as regressors.

\section{RESULTS}

Figure 2 displays the low $(r=.12)$ and insignificant correlation between the 1975-2000 change in the Freedom House index and aid as a share of GNP, averaged over 1975-99. Multivariate tests, described in some detail below, confirm that aid on balance has been ineffectual in promoting democracy.

Table 2 presents these results. In equation 1, the dependent variable is the change in the Freedom House democracy index from 1975-2000, and the aid variable is aid/GNP averaged over 1975-99. In equation 2, aid as a share of government spending is substituted for aid/GNP as the aid measure. Equation 3 returns to aid/GNP as the aid measure, but substitutes the Polity 
democracy index for the Freedom House index.

In these regressions, the aid coefficients are small, of varying sign, and never come close to attaining statistical significance. Among the control variables, the initial value of the democracy index is the most powerful predictor of changes in the democracy indexes; its coefficient is negative as expected, and highly significant in every regression. Initial income and illiteracy levels are never significant. Larger declines in illiteracy, surprisingly, are associated with significant declines in democracy over the period: each 10-point drop in illiteracy is associated with a 1-point rise on the 14-point Freedom House scale (equations 1 and 2). Changes in illiteracy are not significantly related to the Polity index, however (equation 3). Economic growth is positively related to democratization as expected, but more often than not this relationship is not significant at the .05 level in Table 2 . The "third wave" regional dummies are positive, and significant in the majority of cases. Of these, the coefficient for the Latin America dummy is the largest and most significant.

Equation 4 of Table 2 replicates equation 1, but using ordered logit instead of OLS. Ordered logit is an estimation method designed for dependent variables that are ordinal but not interval level. The Freedom House and Polity indexes are typically treated as interval-level measures (e.g. Barro, 1997; Burkhart and Lewis-Beck, 1994), but are technically only ordinallevel scales, despite having up to 25 different possible values (ranging from +12 to -12 ) in the case of Freedom House, and 41 possible values (+20 to -20$)$ for the Polity index. ${ }^{11}$ In equation 4 , ordered logit estimates confirm the absence of a link between aid and democratization.

Equation 5 also replicates equation 1, but using median regression, which reduces the 
sensitivity of results to outlying values, instead of OLS. Aid still shows no impact on democratization in this test.

Equation 6 analyzes changes in the Freedom House index from 1990-2000, adjusting aid/GNP and other independent variables to conform to this 10-year period. Aid was conceivably more effective in this post-Cold War period, in which donors likely gained leverage relative to recipient nations, which could no longer play the superpowers off against one another. In particular, aid was less likely to be used for propping up pro-U.S. dictators, which may have forestalled democratization during the Cold War. Equation 6 shows, however, that aid is unrelated to democratization in the post-cold War period.

Equation 7 returns to the specification in equation 1, but is estimated using two-stage least squares (2SLS) to correct for possible reverse causation. Endogeneity of aid is potentially a serious problem in studying the impact of aid on democratic transition. For example, USAID currently has an explicit policy of directing more aid toward countries that appear to be making greater progress on democratization. Targeting aid toward countries which appear to be making progress in democratizing would bias aid coefficients in a positive direction in OLS regressions. Even with this potential upward bias, equations 1-6 fail to link aid with democratization. However, it is possible that other donors may allocate aid differently in ways that produce a bias in the opposite direction. Accordingly, equation 7 corrects for potential endogeneity by estimating the relationship between democratization and the exogenous component of aid.

Exogenous instruments for aid in the first-stage regression include measures of recipient need and of donor interest. Infant mortality (in 1975) is a measure of recipient need. Country 
size, measured as the log of population of the recipient nation in 1975 , is a measure of donor interest that strongly predicts aid levels. Smaller nations receive much more aid on average than larger nations, presumably because of donors' desire to "show the flag" widely. Other measures of donor interest included as instruments are a set of colonial heritage dummies, indicating whether recipient nations are ex-colonies of any one of eight donor nations (Britain, France, Spain, Portugal, Belgium, Italy, the Netherlands, and the US). Collectively these instruments are effective in explaining aid: the first-stage regression of aid/GNP on these instruments and on the other regressors in the democracy equation in Table 2 produces an $\mathrm{R}^{2}$ of .69, compared to only .49 for a regression of aid/GNP on only the other regressors in Table 2. Aid as instrumented by these variables remains an insignificant predictor of changes in democracy in equation 7 . This result indicates that the insignificant OLS coefficients on aid are not biased downward from any propensity of donors to target aid towards countries experiencing setbacks in democratization.

An alternative, informal approach to exploring the direction of causality is to compare the strength of democratization's relationships with aid early in the period and late in the period. If aid averaged over 1975-89, for example, turned out to be strongly related to democratization (measured over the full period 1975-2000), that would suggest aid encourages democratization. On the other hand, if aid disbursed later in the period, for example 1990-99, were more strongly related to democratization (again, measured over the full period), that would suggest aid is allocated as a reward for prior or ongoing democratization. In fact, aid over each of these subperiods has equally small and insignificant relationships with democratization, when they are substituted for the full-period aid variable in regressions otherwise identical to those in Table 2. 
Table 3 reports OLS regressions for specifications that differ somewhat from those reported in Table1. If aid promotes democracy indirectly through increasing per capita incomes ${ }^{12}$ or through improving access to education, those variables could capture part of any positive impact aid might have on democracy. Therefore, equation 1 of Table 2 omits per capita income growth and changes in illiteracy from the regressions. Results in equation 2 , however, show no evidence that aid promotes democracy through increasing incomes or improving education, as aid remains insignificant.

Equation 2 shows that aid remains insignificant in a specification that includes a more exhaustive set of regressors. This test adds an alternative measure of modernization: urbanization (the 1975 level, and the change from 1975 to 1999). Religious composition has also been linked to democratization (e.g. Barro, 1997 and Clague et al., 2001), so percent Muslim, percent Protestant, and percent Catholic were added. ${ }^{13}$ Adding all of these regressors leaves the aid coefficient insignificant. Of the added regressors, only percent Muslim is significant (at the .06 level). An increase of nearly 40 percentage points in percent Muslim is associated with a decline of about 1 point on the Freedom House index.

Results from three additional tests are not reported in the tables for space reasons. First, aid's impact on democratization might depend on the initial level of democracy. Democracy assistance from USAID tends to focus more on countries already experiencing some democratic openings, rather than on hard-core autocracies (Carothers, 1999), reflecting beliefs about where such aid is likely to be most efficacious. Accordingly, an interaction term equal to the product of aid/GNP and initial democracy level, was added to the regressions. This interaction provided to 
be insignificant, indicating no general tendency for aid to be more efficacious in recipients with either low or high initial levels of democracy. Second, the insignificance of aid potentially could be attributed to multicollinearity, as aid/GNP is correlated with illiteracy at .56 and with initial per capita income at -.56. However, when either or both of those variables are deleted from the regression, aid remains unrelated to democratization. Third, aid remains unrelated to democratization when the dependent variable used is the end-of-period (2000) level of democracy, rather than the change over time from 1975-2000.

\section{CONCLUSIONS}

Both the Freedom House and Polity indexes indicate clear trends toward democratization over the 1975-2000 period. As shown in Figures 3 and 4, the number of aid-recipient nations with improved democracy ratings far exceeds the number with reduced ratings. Results from this study, however, indicate that little if any of this progress can be attributed to foreign aid.

This weak relationship between aid and democratization cannot be attributed merely to a lack of variation over time in the democracy indexes. Figures 3 and 4 indicate that the ratings for most aid recipients were not static. The median shift on the 2-14 point Freedom House scale over the $1975-2000$ period was 2 points, and for the Polity index was 5 points. Moreover, significant and strong relationships are found between changes in these indexes and several other variables, most notably the initial level of democracy. Donor agencies find the Freedom House indexes sufficiently useful that many of them actually use these indexes in tracking progress toward democratization in recipient countries. ${ }^{14}$

Findings from this analysis should be interpreted with caution, however. For example, 
results do not necessarily suggest that funding for democracy promotion should be curtailed. The lack of any relationship between aid and improvements in democratic governance does not imply that none of the democracy-promoting projects sponsored by donors have any effects. The available data on aid do not permit disaggregation of aid intended to promote democracy aid from aid intended to achieve other objectives. The evidence presented here does suggest that either the favorable impacts of aid on democratization are minor, or they are roughly balanced by other democracy-undermining effects of aid dependence. Cross-country, highly aggregated studies such as this one must be complemented by case study evidence that more closely examines the effectiveness of particular democracy-promoting programs (e.g. Carothers, 1999; McMahon, 2002; Blair, 2002). Even were such studies to indicate that current approaches are mostly ineffective, that would not imply that no conceivable democracy-promoting efforts would be efficacious. Moreover, the developed democracies may be able to promote democracy through non-aid channels, including trade, foreign direct investment, and diplomacy (Allison and Beschel, 1992). 
Appendix

The Freedom House Democracy Indicators

Since the early 1970s, the Comparative Survey of Freedom, published by Freedom House, has provided cross-country indexes of "civil liberties" and "political freedoms." Countries are assigned scores from 1 to 7 , with smaller values assigned to countries with greater liberties. Values are based on judgments for each country on the following set of criteria.

\author{
Civil liberties \\ media/literature free of political censorship \\ open public discussion \\ freedom of assembly \& demonstration \\ freedom of political organization \\ nondiscriminatory rule of law/independent judiciary \\ freedom from unjustified terror or imprisonment \\ free trade unions, peasant organizations \\ free business or cooperatives \\ free professional or other private organizations \\ free religious institutions \\ personal social rights: property, travel, residence, family \\ socioeconomic rights; freedom from dependency on landlords, etc. \\ freedom from gross socioeconomic inequality \\ freedom from gross government indifference or corruption

\section{Political freedoms} \\ chief authority recently elected by a meaningful process \\ legislature recently elected by a meaningful process \\ fair election laws, campaigning opportunity, polling and tabulation \\ fair reflection of voter preference in distribution of power \\ multiple political parties \\ recent shifts in power through elections \\ significant opposition vote \\ free of military or foreign control \\ major group or groups denied reasonable self-determination \\ decentralized political power \\ informal consensus; de facto opposition power
}




\section{References}

Allison, G. T. and R. P. Beschel (1992) “Can the United States Promote Democracy?” Political Science Quarterly 107(1): 81-98.

Almond, G. and G. B. Powell (1965) Comparative Politics: A Developmental Approach. Boston, MA: Little Brown.

Apodaca, C. (2001) “Global Economic Patterns and Personal Integrity Rights After the Cold War.” International Studies Quarterly 45: 587-602.

Barro, R. (1997) Determinants of Economic Growth. Cambridge, MA: MIT Press.

Blair, H. (2002) “Assessing Civil Society Impact for Donor-Assisted Democracy Programs: Using an Advocacy Ladder in Indonesia and the Philippines." Presented at American Political Science Association annual meetings, August 29-September 1, Boston MA.

Blanton, S. L. (2000) "Promoting Human Rights and Democracy in the Developing World: U.S. Rhetoric versus U.S. Arms Exports.” American Journal of Political Science 44(1): 123-31.

Boone, P. (1996) "Politics and the Effectiveness of Foreign Aid." European Economic Review 40: 289-329. 
Brautigam, D. (2000) Aid Dependence and Governance. Stockholm: Almqvist \& Wiksell International.

Brautigam, D. (1992) "Governance, Economy, and Foreign Aid." Studies in Comparative International Development 27(3): 3-25.

Burkhart, R. and M. Lewis-Beck (1994) “Comparative Democracy: The Economic Development Thesis." American Political Science Review 88(4): 903-10.

Burnside, C. and D. Dollar (2000) "Aid, Policies, and Growth." American Economic Review, 90(4): 847-68.

Carothers, T. (1999) Aiding Democracy Abroad: The Learning Curve. Washington, DC: Carnegie Endowment for International Peace.

Cingranelli, D. L. and T. E. Pasquarello (1985) "Human Rights Practices and the Distribution of U.S. Foreign Aid to Latin America.” American Journal of Political Science 29(3): 539-63.

Clague, C., S. Gleason and S. Knack (2001) "Determinants of Lasting Democracy in Poor Countries: Culture, Development, and Institutions." Annals of the American Academy of Political 
and Social Science 573: 16-41.

Collier, P. (1997) "The Failure of Conditionality." In Perspectives on Aid and Development, edited by C. Gwin and J. M. Nelson, pp. 52-77. Washington, DC: Overseas Development Council.

Crawford, G. (1997) "Foreign Aid and Political Conditionality: Issues of Effectiveness and Consistency." Democratization 4(3): 69-108.

Dashti-Gibson, J., P. Davis and B. Radcliff (1997). "On the Determinants of the Success of Economic Sanctions: An Empirical Analysis.” American Journal of Political Science 41(2): 60818.

Dollar, D. and L. Pritchett (1998). Assessing Aid: What Works, What Doesn't, and Why. New York: Oxford University Press.

Easterly, W., R. Levine and D. Roodman (2003). "New Data, New Doubts: Revisiting 'Aid, Policies and Growth." Center for Global Development Working Paper No. 26.

Freedom House (various years). Freedom in the World. Westport, CT: Greenwood Press. 
Friedman, M. (1958) “Foreign Economic Aid: Means and Objectives.” Yale Review 47(4): 500516.

Gleditsch, K. S. and M. D. Ward (2000) "War and Peace in Space and Time: The Role of Democratization." International Studies Quarterly 44(1): 1-29.

Grossman, H. I. (1992) “Foreign Aid and Insurrection.” Defense Economics 3: 275-88.

Hufbauer, G. C., J. J. Schott and K. A. Elliott (1990) Economic Sanctions Reconsidered: History and Current Policy ( $2^{\text {nd }}$ ed.). Washington DC: Institute for International Economics.

Huntington, S. (1991) The Third Wave: Democratization in the Late Twentieth Century. Norman, OK: University of Oklahoma Press.

International Financial Institution Advisory Commission (2000) Final report to the Joint Economic Committee, Congress of the United States, March 8.

Isham, J., D. Kaufmann and L. Pritchett (1997) “Civil Liberties, Democracy, and the Performance of Government Projects." World Bank Economic Review 11(2): 219-42.

Karl, T. L. (1997) The Paradox of Plenty: Oil Booms and Petro-States. Berkeley: University of 
California Press.

Knack, S. (2001). "Aid Dependence and the Quality of Governance." Southern Economic Journal 68(2): 310-29.

Lipset, S. M. (1959) “Some Social Requisites of Democracy: Economic Development and Political Legitimacy." American Political Science Review 53(1): 69-105.

Maren, M. (1997) The Road to Hell: The Ravaging Effects of Foreign Aid and International Charity. New York: The Free Press.

Marshall, M. G. and K. Jaggers (2002) Polity IV Project: Political Regime Characteristics and Transitions, 1800-1999 (www.bsos.umd.edu/cidcm/polity/).

McCormick, J. M. and N. Mitchell (1988) "Is U.S. Aid Really Linked to Human Rights in Latin America?" American Journal of Political Science 32(1): 231-9.

McMahon, E. R. (2002) “The Impact of U.S. Democracy Assistance in Africa: Benin Case Study.” Presented at American Political Science Association annual meetings, August 29September 1, Boston MA. 
Meernik, J., E. L. Krueger and S. C. Poe (1998). “Testing Models of U.S. Foreign Policy:

Foreign Aid During and After the Cold War." Journal of Politics 60: 63-85.

Moore, M. (1998) “Death Without Taxes: Democracy, State Capacity, and Aid Dependence in the Fourth World." In Towards a Democratic Developmental State, edited by G. White and M. Robinson. Oxford: Oxford University Press.

North, D. C. (1990). Institutions, Institutional Change, and Economic Performance. Cambridge: Cambridge University Press.

Przeworski, A. and F. Limongi (1997) "Modernization: Theories and Facts.” World Politics 49: $155-83$

Svensson, J. (2000) "Foreign Aid and Rent-Seeking." Journal of International Economics 51(2): $437-61$.

Svensson, J. (1999) "Aid, Growth and Democracy." Economics \& Politics 11: 275-97.

Tilly, C. (1990) Coercion, Capital and European States, A.D. 990-1990. Oxford: Basil Blackwell. 
USAID (1998) “Democracy and Governance: A Conceptual Framework.” November (available at http://www.info.usaid.gov).

World Bank (2003) Global Development Finance 2003: Striving for Stability in Development

Finance. Washington, DC. 


\section{Endnotes}

${ }^{1}$ See the USAID web site (http://www/info.usaid.gov) for more detail on these technical assistance programs in various countries.

${ }^{2}$ The U.S. provided $\$ 11.4$ billion in Official Development Assistance (ODA) to recipient nations and multilateral organizations in 2001. Total ODA by all donors in 2001 was $\$ 52.3$ billion, down from $\$ 58.9$ billion in 1995, reversing an upward trend in the 1980s and early 1990s (World Bank, 2003). Adjusting for inflation, the decline from 1995 to 2001 would be even larger.

3 “USAID: A Record of Accomplishment" (http://www/info.usaid.gov/about/accompi.html).

${ }^{4}$ Studies of economic sanctions (including trade sanctions or freezing of financial assets) conclude that they are usually unsuccessful (e.g., see Hufbauer, Schott and Elliott, 1990). Dashti-Gibson, Davis and Radcliff (1997) find evidence of a downward trend over time in the effectiveness of sanctions.

${ }^{5}$ There are numerous precedents for using a combined index of the two Freedom House indicators, including Burkhart and Lewis-Beck (1994). Results reported below using the combined index do not differ materially when either of the separate indexes are used instead. ${ }^{6}$ Aid per capita is a third possible measure of aid intensity. Although results in section 4 are reported using only aid/GNP and aid/government spending, no findings are changed when aid per capita is used instead.

${ }^{7}$ Because democratization is a long-term process, the analysis does not attempt to explain yearto-year variations in the democracy indexes using annual data. It would also have been far more difficult to correct for the endogeneity of aid using annual data, because of the lack of exogenous 
determinants of aid for which annual data are available. Analyses of how human rights protection influences aid allocations (basically the reverse of the causal direction of this paper) typically rely on annual data (e.g. Apodaca, 2001), often for only one or two years (e.g. Cingranelli and Pasquarello, 1985).

${ }^{8}$ Values for a single year could be anomalous for some countries. Accordingly, averages were computed for 1974-76, and for 1998-2000. However, the change over time in these values is correlated at .98 with the change from 1975 to 2000 . For simplicity, the latter was used in the analysis.

${ }^{9}$ A shorter period is covered for some countries, because of data limitations or because a country became independent only after 1975 .

${ }^{10}$ Data for income growth, initial income level, literacy, and population are all taken from the World Bank's World Development Indicators data base.

${ }^{11}$ The actual range in the sample is +10 (Benin and Panama) to -8 (Gambia) for Freedom House, and +17 (Hungary, Mongolia, Nicaragua, Poland and Uruguay) to -14 (Belarus and Pakistan) for Polity.

${ }^{12}$ Studies generally show that aid on average is not effective in raising per capita incomes (Boone, 1996; Burnside and Dollar, 2000).

${ }^{13}$ Changes in these variables occur only slowly over time and are not measured reliably, so only levels were included as regressors.

${ }^{14}$ For example, USAID, "Building Democracy in Africa" 
(http://www.info.usaid.gov/democracy/afr/africa.html). 